\title{
Desmid flora of mires in Central and Northern Moravia (Czech Republic)
}

\author{
Petra Mazalová, Jana Štěpánková \& Aloisie Poulíčková
}

\begin{abstract}
Desmid flora of mires in Central and Northern Moravia (Czech Republic). - Čas. Slez. Muz. Opava
\end{abstract} (A), 62: 1-22, 2013.

\begin{abstract}
In contrast to higher plants, diversity and distribution of microalgae is not very well understood and floristic data is incomplete for many regions. This study focuses on filling this gap in case of desmids in the region, Moravia (Czech Republic). During the years 2008-2012, desmid flora of nine Moravian (Czech Republic) peat bogs and wetlands were studied. One hundred and nine taxa belonging to 14 genera have been found, 42 of them are new records for Moravia, and five of them are new for the Czech Republic (Closterium cf. costatum var. westii, Cosmarium asphaerosporum var. strigosum, C. exiguum var. pressum, C. incertum, C. transitorium). Species which have been found are briefly discussed with regard to their previous records for Moravia or for the whole Czech Republic. Line drawings of 66 taxa are included. Character and origin of the unique locality Slavkov mire is discussed.
\end{abstract}

Key words: Conjugatophyceae, Desmidiales, diversity, Moravia, mires

\section{Introduction}

Several studies carried out in Moravia (east part of the Czech Republic) have been conducted with diversity of desmids. However, the majority of these studies are more than 50 years old and deal only with habitats in the Jeseníky Mts (Fischer 1924, 1925; Lhotský 1949; Růžička 1954, 1956, 1957; Rybníček 1958). It is a logical approach, because there are famous desmid-rich localities in this part of Moravia. Although desmids can be present in various types of freshwater habitats, including eutrophic waters or even ice, they prefer mesotrophic to oligo-mesotrophic acidic waters and Sphagnum bog pools (Coesel 1975; Brook 1981; Coesel and Meesters 2007). The Jeseníky Mts had been covered by glacier in the last ice age and there were good conditions for the formation of oligotrophic and oligo-mesotrophic raised bogs and transitional peat bogs (Reichholf 1998). In recent studies, special attention has been paid to diatom and desmid flora of ombrotrophic mires in the Jeseníky Mts (Štěpánková et al. 2012, Poulíčková et al. 2013), spring fens in the West Carpathians (Poulíčková 1987; Kitner et al. 2004) and epipelic assemblages of few fishponds (Hašler et al. 2008).

The most comprehensive study on desmids in the Czech Republic focused on Bohemia (western part of the Czech Republic) and included only six Moravian localities (Št'astný 2010), thus desmid floristic data is still incomplete. Particularly, in such areas like the Libavá military training area that have never been sampled before.

The main objective of this study is to deepen our knowledge of the occurrence and species composition of desmids in Moravia. Sampling sites were concentrated on wetland habitats such as transitional peat bogs and peat meadows, which represent the most desmid rich habitats of this region. Such habitats are situated mainly in Central and Northern Moravia, while they are lacking in the eastern and southern part. In accordance with this distribution pattern, we focused on the first mentioned area except for ombrotrophic peat bog localities in the Jeseníky Mts which were already well described by Štěpánková et al. (2012).

\section{Material and methods}

In the period of four years (from 2008 to 2012), 67 samples from nine Moravian localities were taken. Various types of wetland habitats including diverse bogs and fens, wet peat meadows, marshes or ephemeral ditches were sampled. The geographic position of all sampling sites listed bellow is plotted on a map (Map 1). 
Samples were collected by squeezing out the mosses (especially Sphagnum spp.), and submerged macrophytes. For collecting the algae from the sediment a plastic pipette was used. A part of each sample was left for LM observations of living material. The rest of samples was fixed by formaldehyde to a final concentration of $2 \%$ on the day of collecting. Samples were examined under the light microscope Zeiss Primo Star. Desmids were identified using both living and fixed material according to: Coesel $(1982,1983)$, Coesel and Meesters (2007), Lenzenweger (1997, 1999), Růžička (1977, 1981) and West and West (1905, 1908, 1912). In the overview of taxa found during our study, some desmids are presented as rare and/or new for Moravia or even for the whole Czech Republic. Rareness of the taxa was evaluated according to Poulíčková et al. (2004), Št'astný (2010) and other literature cited.

Environmental variables ( $\mathrm{pH}$, conductivity) of water were measured using a $\mathrm{pH} /$ conductivity meter COMBO by Hanna (HI 98129).

\section{List of sampling sites, their geographic position and basic characteristic:}

1. Mesotrophic transitional peat bog „Pstruží potok” Nature Reserve (4957'1"N, 17013'1"E) - Jeseníky Mts Protected Landscape Area; $\mathrm{pH}=6.3-6.4$, cond. $=76-177 \mu \mathrm{S} . \mathrm{cm}^{-1}$.

2. Mesotrophic transitional peat bog „Skalské rašeliniště” Nature Reserve (49 55'10"N, 17²12'23"E); pH = 5.96.4 , cond. $=43-110 \mu \mathrm{S} . \mathrm{cm}^{-1}$.

3. Oligo-mesotrophic transitional peat bog „Rašeliniště Skřítek” National Nature Reserve (49 59'33"N, 179'56"E) - Jeseníky Mts Protected Landscape Area; $\mathrm{pH}=6.9-7.8$, cond. $=22-106 \mu \mathrm{S} . \mathrm{cm}^{-1}$.

4. Fen and waterlogged meadows „Filipovické louky” Nature Reserve (509'42"N, 179'59"E) - Jeseníky Mts Protected Landscape Area; $\mathrm{pH}=7.9$, cond. $=74 \mu \mathrm{S} . \mathrm{cm}^{-1}$.

5. Bog spruce forest „Panské louky” Nature Reserve $\left(49^{\circ} 49^{\prime} 56^{\prime \prime} \mathrm{N}, 17^{\circ} 26^{\prime} 1\right.$ "E); pH = 6.4-8.5, cond. = 62-260 $\mu \mathrm{S} . \mathrm{cm}^{-1}$.

6.a Bog between the hills „Radeška” and „Strážisko” (49³8'4"N, 17²9'57"E) - Libavá military training area; $\mathrm{pH}=6.9-8.7$.

6.b Mesotrophic ephemeral ditches nearby the hill „Strážisko” (49³8'19"N, 17²8'46"E) - Libavá military training area.

7. Sphagnum pools, pools with Utricularia spp. and fen hollows near the village Slavkov by Olomouc (49³4'16"N, 17³3'32"E) - Libavá military training area; $\mathrm{pH}$ 4.3-5.8.

8. Sphagnum pools in the area of the „Podbělka” and „Sušina” hills and the „Mokřiny” site $\left(50^{\circ} 9^{\prime} 50^{\prime N}\right.$, 1651'19"E) - Králický Sněžník Mts Protected Landscape Area; pH = 4.2-5.13, cond. = 30-360 $\mu$ S.cm ${ }^{-1}$.

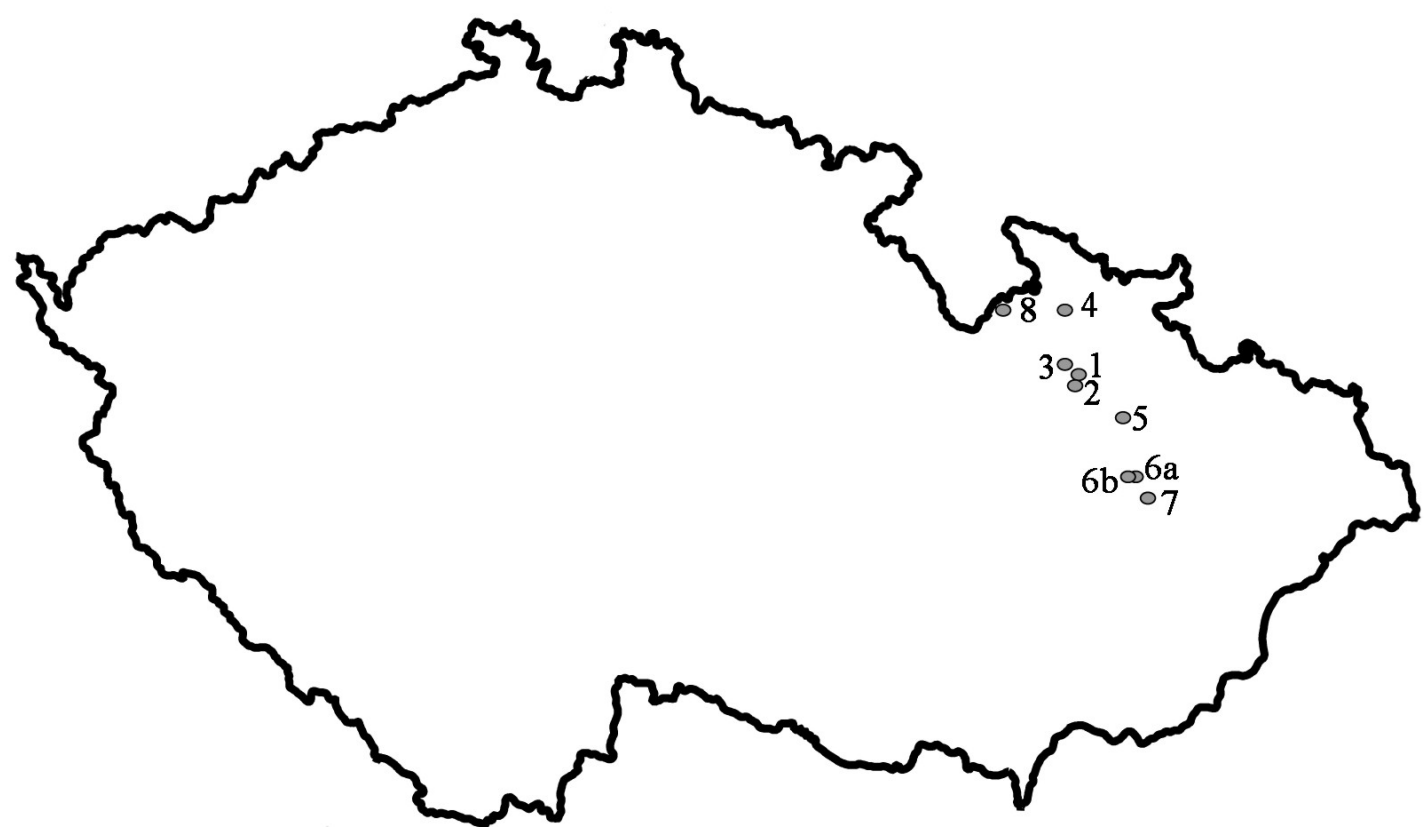

Map 1: Map of the sampling sites. 


\section{Results and discussion}

\section{Ecological part}

According to Št'astný (2005) there could occur around 500 desmid species in the Czech Republic. His estimates are based on complex study of desmid flora in Bohemia and data known from Central Europe, particularly the Netherlands and Austria (Coesel 1998 and Lenzenweger 2003). A total of 109 desmid taxa were identified at nine localities in Central and Northern Moravia, which represent at least one-fifth of the taxa estimated to be present in the Czech Republic. The species richness per locality ranged from 5 to 50 taxa and its distribution pattern corresponded with the main ecological gradients.

The most important ecological variable influencing microalgal distribution in mires seems to be $\mathrm{pH}$ and conductivity (Neustupa et al. 2009; Poulíčková et al. 2013). The high occurrence of desmid species appears to be correlated with low conductivity, calcium and alkalinity levels, $\mathrm{pH}$ values between 5.1-7.0, and the presence of free $\mathrm{CO}_{2}$ (Woelkerling \& Gough 1976; Růžička 1977, 1981; Brook 1981; Lenzenweger 1997). Desmids prefer mesotrophic to oligomesotrophic waters (Coesel 1975; Coesel and Meesters 2007). Their absence in eutrophic waters with nutrient-rich conditions is according to Coesel (2001) caused by the absence of competitiveness to taxa with higher growth rates. Moreover, $\mathrm{pH}$ in eutrophic waters is usually increasing above 8.3 (particularly with the peak of photosynthesis) and limitation by free $\mathrm{CO}_{2}$ can be expected in such conditions (Poulíčková 2011).

The study sites represent wetland habitats, their $\mathrm{pH}$ ranged from 4.2 to 8.7 , conductivity ranged from 22 to $360 \mu \mathrm{S} . \mathrm{cm}^{-1}$ and expected trophic level ranged from oligo-mesotrophic to slightly eutrophic. Most desmid species were recorded from the mesotrophic transitional peat bog „Pstruží potok” with pH values between 6.3-6.4. Low species richness was found at neutral and slightly alkalic localities „Filipovické louky” and „Panské louky”.

The most frequent taxa, occurring at five or more localities were Cylindrocystis brebissonii, Netrium digitus, Closterium striolatum, Closterium rostratum and Closterium lunula. Some of these species are traditionally defined as species typically inhabiting acidic peat bogs (Cylindrocystis brebissonii, Netrium digitus, Closterium striolatum), others are most common in slightly acidic to neutral waters (Closterium rostratum and Closterium lunula). However, they are also known for their relatively wide ecological valence in different pHs, e.g. Closterium striolatum - 4.0 to 7.0, Closterium rostratum - 3.9 to 7.0 or Closterium lunula - 4.5 to 8.0 (Růžička 1977; Coesel \& Meesters 2007).

Among desmids found during our study, the following taxa are new, unrecorded in the Czech Republic: Closterium cf. costatum var. westii, Cosmarium asphaerosporum cf. var. strigosum, $C$. exiguum var. pressum, $C$. incertum, $C$. transitorium (they are designated with a triangle $\boldsymbol{\Delta}$ before the species name). Relatively high number of new taxa for Moravia (42 taxa - designated with an asterisk * before the species name) illustrate the lack of knowledge in this area.

Besides diatoms, desmids belong to the best bioindicators. Diversity and species composition of their assemblages correlates with character of a biotope quite well (Coesel 1998, 2001; Št'astný 2010). That is why we paid special attention to characterize the locality Slavkov mire (no. 7), which has been discovered quite recently by field botanists. Desmids probably represent the first group of organisms, which species list will be published for this locality.

The locality is particularly interesting because of the occurrence of higher plant taxa as Eriophorum vaginatum and Vaccinium uliginosum (leg. Zbyněk Hradílek). Their local populations are geographically isolated from others situated as far away as the mountain bogs in the Jeseníky Mts. (about $80 \mathrm{~km}$ far), suggesting a possible Holocene relic character of the Slavkov mire (Zbyněk Hradílek, personal communication). Regarding these finds, the locality could be considered to be valuable also because of its genesis. Its potential character of the 
Holocene relic must be confirmed by further analyses. In such case, nomination of the Slavkov mire among protected areas would be desirable. Indeed, the character of this unique locality seems to be confirmed by desmid floristic data.

During our study, 22 desmid taxa were identified here. Among these, the following taxa are remarkable in relation to their distribution pattern. Staurastrum senarium and $S$. gladiosum are rare species, indicative for stable ecosystems and they appear to be bound to Holocene peat bogs (Coesel 1997, 1998; Coesel \& Meesters 2007; Št'astný 2010). Regarding the origin of habitats, similar preferences have been reported for Euastrum ansatum, E. elegans, Micrasterias thomasiana var. notata. Besides the Holocene site, species were collected at the Pleistocene mires as well (Coesel 1985).

\section{Taxonomic part}

Systematical classification of species found during our study (bellow) corresponds to the conception of Desmidiales s.l., which contains the family Mesoteniaceae and the order of Desmidiales s.s. with families Gonatozygaceae, Peniaceae, Closteriaceae and Desmidiaceae (Mix 1972).

\section{Family Mesotaeniaceae}

\section{Cylindrocystis brebissonii De Bary}

Localities: $1,3,5,6 \mathrm{~b}, 8$

In Moravia it is a very common species, particularly in Sphagnum vegetation. Previous records: Fischer (1924, 1925), Kitner et al. (2004), Lhotský (1949), Rosa (1957), Růžička (1956, 1957), Rybníček (1958), Štěpánková et al. (2012).

\section{Cylindrocystis crassa De Bary}

Locality: 6b

This species was very rare, found only in one of the samples. In Moravia previously recorded by Lhotský (1949), who surprisingly refers to widespread occurrence in Moravia, and by Rybníček (1958). According to our experience it is rather rare nowadays. A possible explanation could be that it can be easily confused with Cylindrocystis brebissonii.

\section{Cylindrocystis gracilis I. Hirn}

Synonym: Cylindrocystis brebissonii var. minor W. et G. S. West

Localities: $5,6 \mathrm{~b}$

Up to date, this species has been reported only from Northern Moravia - localities Hrubý Jeseník (Růžička 1957; Štěpánková et al. 2012) and Velká Kotlina (Růžička 1956).

\section{Mesotaenium endlicherianum Nägeli}

Locality: 1

Fig 1: 23

It is a rare species of benthic or subathmophytic habitats (Št’astný 2010). Previous records from Moravia come from Růžička (1957) and Štěpánková et al. (2012).

\section{Mesotaenium macrococcum (Kütz.) J. Roy et Bisset}

Localities: $3,6 \mathrm{~b}$

It was relatively rare. From Moravia previously reported only from the Hrubý Jeseník Mts (Lhotský 1949; Rosa 1957; Štěpánková et al. 2012).

\section{Netrium digitus Itzigs. et Rothe}

Localities: 1, 2, 3, 6b, 7, 8

Fig 1: 15

It was common in acidic habitats, but present also in slightly acidic waters. Previous records from Moravia: Fischer (1924, 1925), Kitner et al. (2004), Lhotský (1949), Růžička (1956, 1957), Rybníček (1958), Štěpánková et al. (2012). 


\section{Family Peniaceae}

\section{Penium polymorphum Perty}

Locality: 3

Together with our findings from Moravia, up to now it was reported only from the Jeseníky Mts (Fischer 1924, 1925; Rybníček 1958; Štěpánková et al. 2012).

\section{*Penium spirostriolatum J. Barker}

Localities: 6a, 6b, 7

Fig 1: 18

Although it is rather common in acidic places, this is the first record of this species from Moravia (except for the record of Lelková et al. 2004, which is doubtful - the authors themselves stated this record with an abbreviation cf.). However, it was previously reported from the Czech Republic - from Bohemia (Nováková 2002; Št’astný 2005, 2007, 2008a, 2009, 2010).

\section{Family Closteriaceae}

\section{*Closterium cf. baillyanum (Ralfs) Bréb.}

Synonyms: Closterium baileyanum Bréb., Cl. didymotocum var. baillyanum Bréb. in Ralfs Locality: 1

\section{Fig 1: 7}

According to Coesel and Meesters (2007) or Růžička (1977), the average value of cell length of this species is around 300-500 $\mu \mathrm{m}$, cell breadth 30-50 $\mu \mathrm{m}$. Dimensions of cells in our material were smaller (L: 230-250, B: 22.5-32 $\mu \mathrm{m}$ ). It is widely known from Bohemia (western part of the Czech Republic; e.g. Št’astný 2005) but there was no record from Moravia until now.

\section{*Closterium calosporum Wittr.}

Synonym: Closterium calosporum $\mathrm{f}$. minus Wille

Locality: 3

It had flattened apices with a clear end pore. In the Czech Republic it is quite common (e.g. Št'astný 2005). New taxon for Moravia.

*Closterium closterioides (Ralfs) A. Louis et Peeters

Synonyms: Closterium libellula Focke ex Nordst., Penium closterioides Ralfs, P. libellula (Focke) Nordst.

Locality: 5

Fig 1: 10

According to Růžička (1977), it prefers acidic to neutral habitats with pH around (4.8)-5.5-7.0. Our samples from locality no. 5 come however from habitat with higher $\mathrm{pH}$ - around 8.2. New taxon for Moravia.

\section{Closterium costatum Ralfs}

\section{Locality: 4}

From Moravia previously recorded by Kitner et al. (2004) in the acidic spring fen Obidová (the Beskydy Mts Protected Landscape Area).

\section{$\Delta$ Closterium cf. costatum var. westii Cushman}

\section{Locality: 1}

Fig 1: 4

However the nominate variety is quite common in the Czech Republic (e.g. Pascher 1906; Roubal 1958; Rosa 1969; Kitner et al. 2004; Št’astný 2007, 2008b, 2009, 2010), variety westii has not been recorded there until now. New taxon for the Czech Republic. According to Růžička (1977), this variety is rather rare in middle Europe. It should be pointed out, that the validity of the taxon is challenged (Rủžička 1977; Št'astný and Kouwets 2012).

\section{*Closterium dianae Ralfs}

Synonym: Closterium acuminatum Kütz. ex Ralfs

Localities: 1,3

It is a widely distributed species in the Czech Republic (e.g. Štastný 2005). In spite of it, this is the first record for Moravia. Some specimens of var. dianae were hardly recognizable from var. minus - transitional forms. 
*Closterium dianae var. minus Hieron.

Synonym: Closterium dianae f. intermedium Kossinskaja

Localities: $1,2,3$

Rather rare in our samples and less common in Bohemia than the nominate variety (Š́tastný 2010). New taxon for Moravia.

\section{* Closterium directum W. Archer}

Synonyms: Closterium ulna Focke ex W.B. Turner, Cl. ulna var. multinucleatum Deflandre, Cl. ulna var. striolato-punctatum Elenkin

Locality: 2

The species was found in a slightly acidic Sphagnum locality. Many reports from Bohemia: from Břehyně and Pískovny Cep (Št’astný 2005), from the Jizerské hory Mts (Štěpánková et al. 2008), from the Krkonoše Mts (Nováková 2002). New taxon for Moravia.

\section{Closterium ehrenbergii Ralfs}

Localities: 1,4

Fig 1: 6

It was present in slightly acidic to slightly alkaline waters. Cells had a great range of dimensions. Previous records from Moravia: Dočkal and Sládeček (1974), Kočárková and Poulíčková (2001), Lelková et al. (2004), Sládečková et al. (1985). Losos and Marvan (1957) found Closterium ehrenbergii var. malinvernianum in Černý potok and Růžička (1954) in the river Moravice and its tributaries (Černý potok and Podolský potok).

\section{*Closterium ehrenbergii var. atumidum Grönblad}

Locality: 3

Cells were strongly arched, without swelling in the ventral side of the mid region (in contrast to the type variety). New taxon for Moravia.

\section{*Closterium incurvum Bréb.}

Synonym: Closterium venus var. incurvum (Bréb.) Krieger

Localities: $2,3,7$

Rather common in acidic, slightly acidic to slightly alkaline waters in Bohemia (Št'astný 2005). New taxon for Moravia.

\section{*Closterium intermedium Ralfs}

Locality: 6a

The species occurred in samples with slightly acidic to neutral water reaction. It is already known from Bohemia (e.g. Šastný 2010). New taxon for Moravia.

\section{Closterium juncidum Ralfs}

Locality: 6a

Fig 1:9

From Moravia known only from the river Moravice and its tributaries until now (Růžička 1954; Losos and Marvan 1957).

\section{Closterium littorale $\mathrm{F}$. Gay}

\section{Locality: 5}

Fig 1: 12

It was rare in slightly alkaline water bodies. From Moravia previously recorded from the Morava river (Poulíčková 1987). According to literature (e.g. Coesel and Meesters 2007) and also according to our experience, it prefers rather eutrophic habitats.

\section{Closterium littorale var. crassum W. et G. S. West}

\section{Locality: 5}

It was rare in slightly alkaline water bodies. Previous records from Moravia from the Moravice river (Losos and Marvan 1957; Rǔžička 1954). 

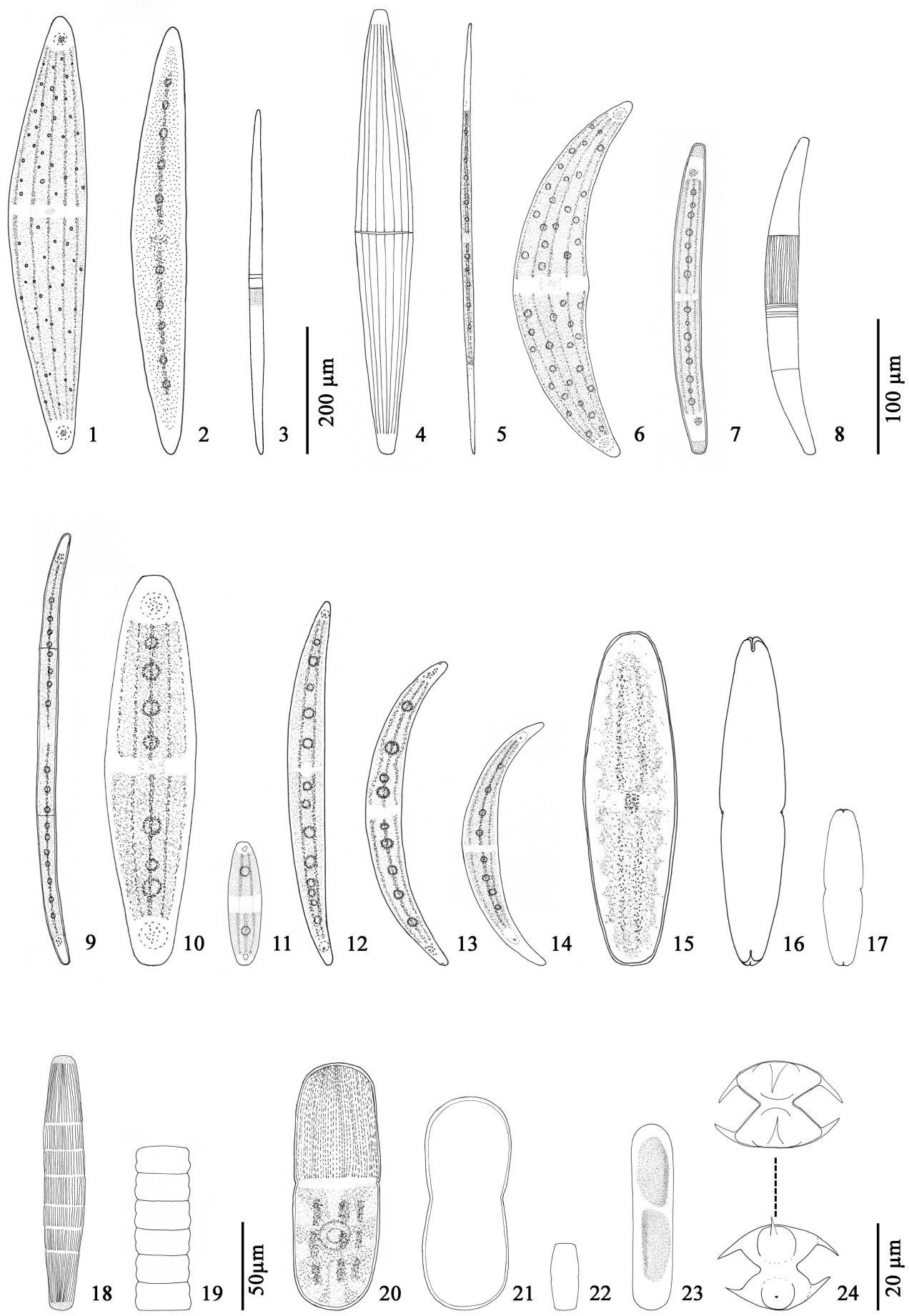

Fig 1: 1 - Closterium lunula, 2 - Cl. cf. pseudolunula, $\mathbf{3}-C l$. cf. pritchardianum var. angustum, $4-C l$. cf. costatum var. westii, $5-C l$. pronum, $\mathbf{6}-\mathrm{Cl}$. ehrenbergii, $\mathbf{7}-\mathrm{Cl}$.cf. baillyanum, $\mathbf{8}-\mathrm{Cl}$. striolatum, $9-\mathrm{Cl}$. juncidum, $10-C l$. closterioides, $11-C l$. navicula, $12-C l$. littorale, $\mathbf{1 3}-C l$. parvulum, $14-C l$. tumidulum, 15 - Netrium digitus, 16 - Tetmemorus granulatus, 17 - T. laevis, 18 - Penium spirostriolatum, 19 - Hyalotheca dissiliens, $\mathbf{2 0}$ - Actinotaenium silvae-nigrae var. parallelum, 21 - A. diplosporum, 22 - A. pinicolum, $23-$ Mesotaenium endlicherianum, 24 - Staurodesmus glaber. Figs 1-3: scale $200 \mu \mathrm{m}$; 4-8: scale $100 \mu \mathrm{m}$; 9-19: scale $50 \mu \mathrm{m} ; 20-24$ : scale $20 \mu \mathrm{m}$. 


\section{Closterium lunula Ralfs}

Localities: 1, 5, 6a, 6b, 7

Fig 1: 1

It was found in acidic, slightly acidic to slightly alkaline water bodies. Previously reported from Obidová in the Beskydy Mts - Protected Landscape Area (Kitner et al. 2004) and from the Morava river (Hindák et al. 2006).

\section{*Closterium moniliferum var. concavum Klebs}

\section{Locality: 3}

This taxon belongs to desmids with a wide ecological valence, so it can occur in slightly acidic to alkaline, mesoeutrophic water bodies (Růžička 1977). In Moravia, Closterium moniliferum Ralfs was previously recorded by Dočkal and Sládeček (1974), Hindák et al. (2006), Kočárková and Poulíčková (2001), Lelková et al. (2004), Růžička (1954). Variety concavum is obviously less common than the nominate variety because this is the first record of it for Moravia.

*Closterium navicula (Bréb.) Lütkem.

Synonyms: Closterium navicula var. granulatum (W. et G. S. West) Krieger, Penium fusiforme F. Gay, P. navicula Bréb., P. navicula f. willei Schmidle

Locality: $6 \mathrm{~b}$

Fig 1: 11

According to Růžička (1977), it is a common species in middle Europe. It prefers slightly acidic water bodies but it can be present also in slightly alkaline waters. Even though it has been repeatedly recorded from localities in Bohemia (Št’astný 2005, 2007, 2008a, 2008b, 2009, 2010; Štěpánková et al. 2008 - var. crassum; Lukavský 2009) this is the first record for Moravia.

\section{Closterium parvulum Nägeli}

Localities: $1,6 \mathrm{a}$

Fig 1: 13

In Moravia it was present in slightly acidic, neutral to slightly alkaline waters. It was previously recorded by Růžička $(1956,1957)$.

\section{*Closterium cf. pritchardianum var. angustum Borzécki}

Locality: 1

Fig 1: 3

The species occurred in slightly acidic water with Sphagnum. Cells were almost straight, thinner than $28 \mu \mathrm{m}$ with truncately rounded apices. Cell wall was irregular punctate at the apices. New taxon for Moravia.

\section{Closterium pronum Bréb.}

\section{Locality: 7}

Fig 1: 5

It was rather common in some of the acidic bog pools in the locality No. 7. From Moravia previously recorded by Pouličková (1987) from the river Morava in Olomouc. In the book „Desmids of the Lowlands” (Coesel and Meesters 2007) the wide ecological range of this species is discussed.

\section{Closterium cf. pseudolunula Borge}

Locality: 1

Fig 1: 2

This species was a rare element in the samples. It was found in slightly acidic water with Sphagnum. Cells were conspicuously larger (reaching up to $680 \mu \mathrm{m}$ ) than the average (Coesel 1983; Růžǐčka 1977). Previous record from Moravia was made by Hašler et al. (2008).

\section{Closterium rostratum Ralfs}

Localities: 1, 2, 3, 4, 5

This species is common in Moravia. We found it in slightly acidic to slightly alkaline habitats. In samples from the peat bog „Pstruží potok” (Locality 1), there were intermediate forms of Closterium rostratum and Closterium kuetzingii present. From Moravia previously recorded by Kitner et al. (2004), Losos and Marvan (1957) and Štěpánková et al. (2012). 
*Closterium rostratum var. brevirostratum $\mathrm{W}$. West

Synonym: Closterium rostratum f. brevirostratum (W. West) Kossinskaja

Locality: 1

This taxon is probably often confused with the variety rostratum. It was very rare in one of the samples. New taxon for Moravia. However, according to Lenzenweger (1996) and Růžička (1977), the validity of this taxon is challenged.

\section{Closterium striolatum Ralfs}

Localities: 1, 2, 3, 5, 6a, 6b, 7

Fig 1: 8

In Moravia, common and in some of our samples, relatively abundant. Our samples had wide range of dimensions: L: 237.5-330, B: 30-35 $\mu \mathrm{m}$. Previous records: Kitner et al. (2004) and Marvan (1998).

\section{Closterium tumidulum F. Gay}

\section{Locality: 1}

Fig 1: 14

This species is known for its wide ecological valence, present also in eutrophic waters (Růžička 1977). From Moravia previously recorded by Hašler et al. (2008), Losos and Marvan (1957), Růžička (1954, 1956, 1957) and Rybníček (1958) from rivers and from stagnant waters.

\section{Closterium tumidum Johns.}

Locality: 6b

From Moravia more records are known: Růžička $(1954,1957)$ and Rybníček (1958). Růžička (1977) regarded this species as rare in Central Europe. But we do not share this opinion. According to us and with respect to the opinion of Štastný (2010), it is probably rather overlooked.

\section{Family Desmidiaceae}

\section{*Actinotaenium colpopelta (Bréb.) Compère}

Synonyms: Actinotaenium colpopelta f. minus (W. West) Compère, A. viride (Corda ex Josh.) Teiling, Colpopelta viridis Corda, Cosmarium colpopelta Bréb. ex W. Archer, C. cordanum Bréb. in Rabenhorst, C. viride (Corda) ex Josh., Dysphinctium viride (Corda) De Toni Locality: 1

It was a very rare species, which we found in slightly acidic water. Also according to Coesel and Meesters (2007) and Rǔžička (1977), this species is rare. Dimensions of our specimens: L: 40-52.5, B: 21.5-25, I: 20-22.5 $\mu \mathrm{m}$. New taxon for Moravia. Our specimens correspond to this depicted by Růžička (1981), Plate 55: Fig. 20.

\section{Actinotaenium cucurbita (Ralfs) Teiling}

Synonym: Cosmarium cucurbita Ralfs

Localities: 1,8

Although it prefers strictly acidic water bodies (Růžička 1981), we found it in an acidic and in slightly acidic waters. Previous records from Moravia: Marvan (1998) and Štěpánková et al. (2012).

Actinotaenium cucurbitinum (Bisset) Teiling Synonyms: Cosmarium cucurbitinum (Bisset) Lütkem., Penium cucurbitinum Bisset Locality: 3

It was rather rare in the samples from a slightly acidic habitat. In Moravia previously found by Kitner et al. (2004).

Actinotaenium diplosporum (P. Lundell) Teiling

Synonym: Cosmarium diplosporum (P. Lundell) Lütkem.

Localities: 1,3

Fig 1: 21

Our specimens occurred in slightly acidic to neutral waters. From Bohemia it is known from the localities Břehyně, Krkonoše Mts (Štastný 2005), Jizerské hory Mts (Štěpánková et al. 2008), Slavkovský les (Trojánková 2006) and from the fishpond Režabinec (var. diplosporum, var. americanum and var. americanum f. minus, Růžička 1973). From Moraviait was previously recorded from Malý Děd in the Hrubý Jeseník Mts (Růžička 1957) and source of the Moravice river (Růžičcka 1956). 


\section{Actinotaenium pinicolum Rosa}

Localities: 1,3

Fig 1: 22

It seems to be a relatively common species in acidic to slightly acidic habitats of Moravia. In the past it was probably often overlooked. Štěpánková et al. (2012) found it in eight localities of the Jeseníky Mts, with a strong preference for subatmophytic sites.

\section{Actinotaenium silvae-nigrae var.parallelum (Krieger) Kouwets et Coesel}

Synonym: Penium silvae nigrae var. parallelum Krieger

Localities: $1,3,8$

Fig 1: 20

It occurred in acidic to slightly acidic waters with Sphagnum. Previously it was recorded by Štěpánková et al. (2012).

\section{Actinotaenium cf. spinospermum (Josh.) Kouwets et Coesel}

Synonym: Penium spinospermum Josh.

Locality: 3

We are not sure with identification, because we did not found the zygospores of the species. Our specimens were present in slightly acidic waters with Sphagnum. They corresponded to these depicted by Růžička (1977) in Table 5: Figs. 12-14. The species was previously reported by Štěpánková et al. (2012).

\section{A Cosmarium asphaerosporum cf. var. strigosum Nordst.}

\section{Locality: 1}

Fig 2: 20

Cells were a little bit narrower and had a broader isthmus than those mentioned in West and West (1905) - the dimensions of our specimens were: L: 10-10.5, B: 7.5-8 $\mu \mathrm{m}$. We found it in slightly acidic Sphagnum water. This is new taxon for the Czech Republic.

\section{Cosmarium botrytis Ralfs}

Localities: 4, 6a

Our specimens came from slightly alkaline waters. They were a little bit bigger than those described in Coesel and Meesters (2007). Dimensions of our specimens were: L: 85-97, B: 65-75 $\mu \mathrm{m}$. It was previously reported by Kitner et al. (2004), Losos and Marvan (1957). Another variety - var. tumidum was reported by Hašler et al. (2008).

\section{Cosmarium caelatum Ralfs}

Localities: 1,3

Fig 2: 9

The species was found in slightly acidic habitats. According to Coesel and Meesters (2007), it is rare in the Netherlands. However, in the Czech Republic it is relatively common, from Moravia reported by Kitner et al. (2004), Růžička (1956), Rybníček (1958) and Štěpánková et al. (2012).

\section{Cosmarium crenatum Ralfs}

\section{Locality: $6 \mathrm{~b}$}

There were no records from Moravia for a long time. The last time it was reported by Růžička (1957) and Rybníček (1958). According to our observations it is rather a rare species.

*Cosmarium decedens (Reinsch) Racib.

Synonyms: Cosmarium carpaticum (Racib.) Migula, C. plicatum var. decedens Reinsch, Euastrum anomalum F. Gay, E. decedens (Reinsch) J. Roy

Locality: 3

Fig 2: 12

Our specimens come from an ephemeral puddle in the neighbourhood of the peat bog „Rašeliniště Skřítek”. It is rare and this is the first record of the species for Moravia. 


\section{Cosmarium difficile Lütkem.}

Locality: 1

Fig 2: 13

It is a relatively common species in the Czech Republic. Previous reports from Moravia: Kitner et al. (2004), Růžička $(1956,1957)$ and Štěpánková et al. (2012).

\section{A Cosmarium exiguum var. pressum W. et G. S. West}

\section{Locality: 1}

Fig 2: 19

Our specimens corresponded to the figures from West and West (1908), Plate 70: Fig. 23-24. The taxon occurred in a large amount's in one of the samples. New taxon for the Czech Republic.

\section{*Cosmarium galeritum Nordst.}

\section{Locality: 1}

Fig 2: 6

The species occurred in a slightly acidic habitat and was rare in one of the samples. From the Czech Republic, it was previously recorded only twice, by Roubal (1938) and Štastný (2010). However, Štastný (2010) found a different morphospecies with just one central pyrenoid. Our finding can be regarded as the first for Moravia.

\section{Cosmarium homalodermum Nordst.}

Synonym: Cosmarium hammeri var. homalodermum (Nordst.) W. et G. S. West Locality: 1

Fig 2: 11

Rather a rare species with variable number of pyrenoids (one or two; Kouwets 1997). Chloroplasts of our specimens contained two pyrenoids in each semicell. In Moravia previously found by Růžička $(1956,1957)$.

\section{Cosmarium hornavanense Gutw.}

\section{Locality: 2}

Fig 2: 7

Dimensions of our specimens: L: 95-97.5, B: 70-72.5 $\mu \mathrm{m}$. Our specimens were a little bit narrower than those described by Lenzenweger (1999). According to Rủžička (1957), it is a common species in mountains of the Czech Republic, however always scattered. From Moravia previously recorded by Růžička $(1956,1957)$ and Rybníček (1958).

\section{$\Delta$ Cosmarium incertum Schmidle}

\section{Locality: 1}

Fig 2: 14

It was very rare, with dimensions: L: 29-31.75, B: 17.75-19 $\mu \mathrm{m}$. New taxon for the Czech Republic.

Cosmarium laeve var. octangulare (Wille) W. et G. S. West

Synonyms: Cosmarium laeve var. undulatum Schmidle, C. meneghinii f. octangulare Wille Locality: 1

The variety was found in a slightly acidic mesotrophic peat bog. Cosmarium laeve was previously reported from Moravia by Losos and Marvan (1957), Rủžička (1954, 1956), Marvan (1998) and Kitner et al. (2004). Rủžička $(1954,1956)$ reported a broad variability in this species and figure No. 19 in the Table 2 (Růžička 1956) seems to be more likely var. octangulare than var. laeve.

\section{Cosmarium nasutum f. granulatum Nordst.}

Locality: 1

Fig 2: 10

According to Kouwets (1999), this forma should be united with the nominal variety. Previous record for Moravia is from the locality Obidová (Kitner et al. 2004).

\section{Cosmarium ochthodes Nordst.}

\section{Localities: 1, 2, 3}

According to Lenzenweger (1999), it is an adaptable species. In our samples, it occurred in slightly acidic water bodies. Relatively wide range of dimensions: $\mathrm{L}: 75-97.5$, B: $62.5-70 \mu \mathrm{m}$. The specimens corresponded to these 
depicted by Lenzenweger (1999), Plate 55: Fig. 5-6. From Moravia it was previously recorded by Růžička (1956).

\section{Cosmarium pachydermum $\mathrm{P}$. Lundell}

Locality: 1

Fig 2: 2

Kitner et al. (2004) found it in three rather acidic Moravian localities: Adámky, Horní Lomná and Obidová. We detected it in the peat meadow „Pstruží potok” which is slightly acidic.

\section{*Cosmarium praemorsum Bréb.}

Locality: 1

This could be the first record of the species from Moravia, because the validity of the only previous record from Růžička (1954) is doubtful. Although the shape and dimensions of his specimens fitted, he was not able to see the ornamentation to be sure with determination.

\section{Cosmarium pseudonitidulum Nordst. var. validum W. et G. S. West}

Localities: 1,3

Fig 2: 3

Other findings from Moravia: Růžička $(1956,1957)$ and Rybníček (1958).

*Cosmarium pseudoornatum B. Eichl. et Gutw.

Locality: $6 \mathrm{~b}$

Fig 2: 15

The species found in a slightly acidic ephemeral pool was already reported from the Czech Republic (e.g. Št'astný 2005, Trojánková 2006). However, this is a new taxon for Moravia.

*Cosmarium quadratum var. willei (Schmidle) Krieger et Gerloff

Synonyms: Cosmarium quadratum f. maius Manguin, C. quadratum f. willei (Schmidle) W. et G. S. West, Dysphinctium quadratum var. willei Schmidle

Locality: 3

Fig 2: 5

We found this variety in a slightly acidic locality. Previous reports from Moravia belong to the nominate variety (Růžička 1956; Rybníček 1958; Losos and Heteša 1972; Kitner et al. 2004; Štěpánková et al. 2012) while variety willei was recorded only recently in Bohemia (Lukavský 2009). New taxon for Moravia.

\section{*Cosmarium ralfsii Ralfs}

Synonyms: Cosmaridium ralfsii (Bréb.) Hansg., Pleurotaeniopsis ralfsii (Bréb.) P. Lundell

Locality: 1

Fig 2: 1

The species found in a slightly acidic habitat is probably rare in Moravia. New taxon for Moravia.

Cosmarium regnellii var. minimum B. Eichl. et Gutw.

Locality: 2

Fig 2: 17

It occurred in a slightly acidic habitat. Previous reports from Moravia are from Hašler et al. (2008) and Štěpánková et al. (2012).

*Cosmarium subcostatum var. minus (W. et G. S. West) Kurt Först.

Synonym: Cosmarium subcostatum f. minus W. et G. S. West

Locality: 7

Fig 2: 16

The variety was found in a slightly acidic bog pool. Cells were a little bit smaller than those described by West and West (1908). Dimensions of our specimens: L: 17.5-18.5, B: 15-17 $\mu \mathrm{m}$. New taxon for Moravia.

\section{Cosmarium subcucumis Schmidle}

Locality: 4

This species found in a slightly alkaline locality was relatively frequently reported from Moravia: Růžička (1954, 1956), Losos and Marvan (1957), Rybníček (1958), Kitner et al. (2004). 

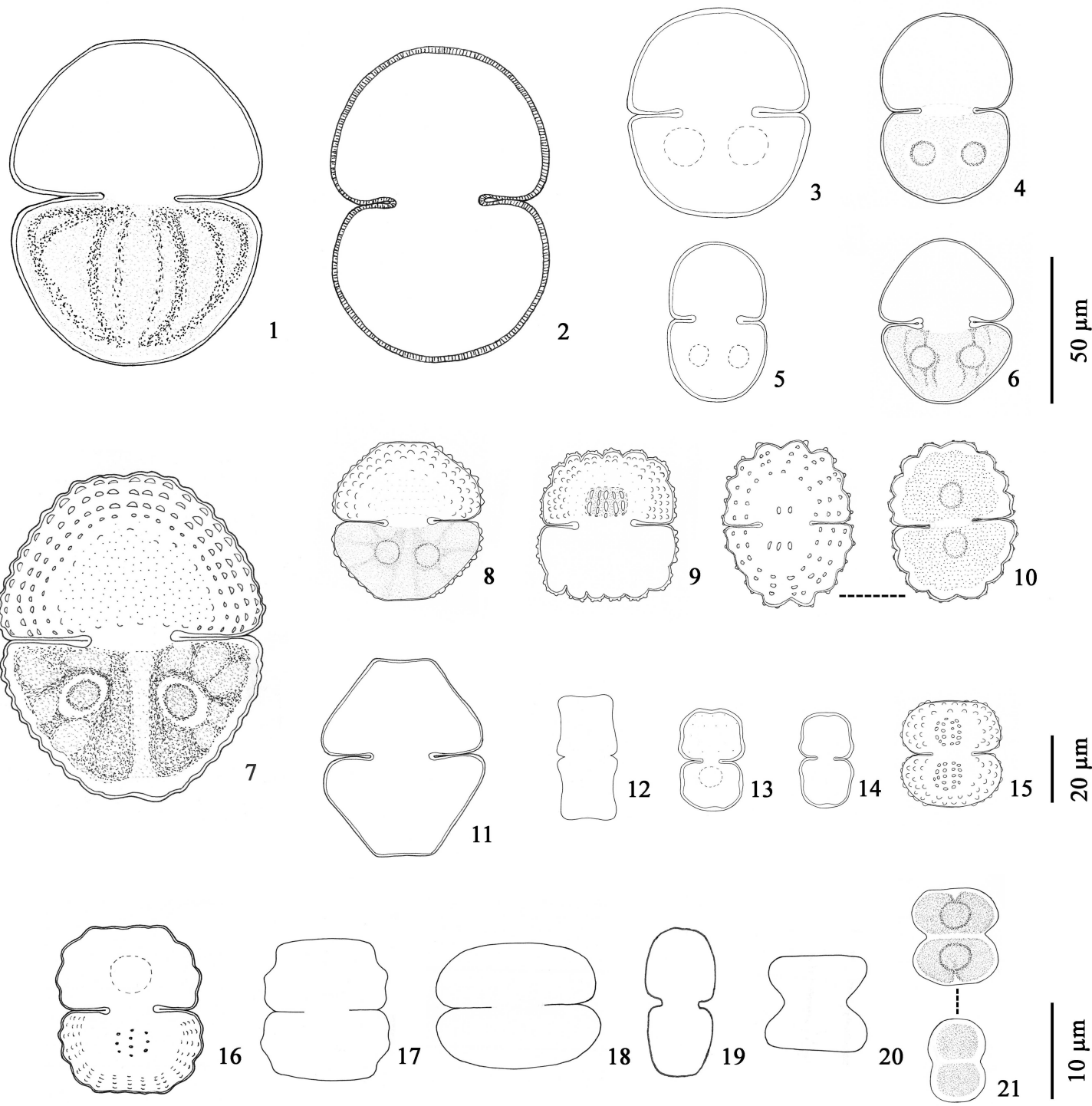

통으

Fig 2: 1 - Cosmarium ralfsii, 2 - C. pachydermum, $\mathbf{3}-$ C. pseudonitidulum var. validum, $\mathbf{4}$ - C. transitorium, 5 - C. quadratum var. willei, $6-C$. galeritum, $7-$ C. hornavanense, $8-C$. vexatum var. concavum, $9-C$. caelatum, $10-C$. nasutum f. granulatum, $11-C$. homalodermum, $12-C$. decedens, $\mathbf{1 3}-C$. difficile, $14-C$. incertum, $15-C$. pseudoornatum, $16-C$. subcostatum var. minus, $17-C$. regnellii var. minimum, $18-C$. subquadrans var. minor, $\mathbf{1 9}-$ C. exiguum var. pressum, $\mathbf{2 0}-$ C. asphaerosporum cf. var. strigosum, $21-C$. tinctum var. intermedium. Figs 1-6: scale $50 \mu \mathrm{m}$; 7-15: scale $20 \mu \mathrm{m} ; 16-21$ : scale $10 \mu \mathrm{m}$.

\section{Cosmarium subquadrans var. minor Symoens ex Coesel}

\section{Locality: 1}

Fig 2: 18

This taxon is rare in the Czech Republic. Our specimens come from a slightly acidic Sphagnum locality. From Moravia previously only recently recorded by Štěpánková et al. (2012).

\section{*Cosmarium tinctum var. intermedium Nordst.}

Locality: 7

Fig 2: 21 
Št'astný (2010) recorded two known varieties of this species from the Czech Republic: nominate variety and var. subretusum. Variety intermedium was found many years ago by Roubal (1958). This is the first record of var. intermedium for Moravia.

$\Delta$ Cosmarium transitorium (Heimerl) Ducellier

Synonym: Cosmarium pachydermum f. transitoria Heimerl

Locality: 1

Fig 2: 4

The species was rarely found on a Sphagnum habitat and this is the first record of it from the Czech Republic.

\section{Cosmarium vexatum $\mathrm{W}$. West}

Locality: 1

It occurred in slightly acidic waters. From Moravia previously reported by Štěpánková et al. (2012). In Moravia, Hašler et al. (2008) found another variety: var. lacustre, a rare taxon in central Europe (Lenzenweger 2003).

\section{*Cosmarium vexatum var. concavum Schmidle}

Localities: 1,2

Fig 2: 8

It requires the same conditions as the nominate variety. The first record from the Czech Republic comes from Št'astný (2010). It is hard to distinguish it from Cosmarium sportella Bréb., which differs only with central ornamentation of semicells (Lenzenweger 1999). Its taxonomic position is challenged by some authors (Guiry \& Guiry 2013). If the taxon is valid, our record is the first for Moravia.

\section{*Euastrum ansatum Ralfs}

Synonyms: Cosmarium ansatum (Ehr.) Corda, C. pseudopyramidatum var. ansatum Krieger et Gerloff, Euastrum ansatum var. commune Ducellier, E. ansatum var. dideltiforme Ducellier, E. ansatum var. emarginatum Hansg., E. ansatum var. simplex Ducellier, E. rotundum Playfair

Localities: $6 \mathrm{a}, 7$

Fig 3: 8-9

According to Růžička (1981), it is a well adaptable species which prefers slightly acidic waters but can also occur in acid Sphagnum waters or in neutral sites. Although it has been frequently reported from Bohemia, records from Moravia do not exist. The only record from Moravia is from Kitner et al. (2004), who reported Euastrum ansatum var. pyxidatum from locality Obidová. New taxon for Moravia.

\section{Euastrum bidentatum Nägeli}

Locality: $6 \mathrm{~b}$

Fig 3: 10

Rǔžička (1981) stated that the nominate variety of Euastrum bidentatum is common in Central Europe. It prefers meso-oligotrophic moorland pools and fen hollows (Coesel and Meesters 2007). Previous record from Moravia: Štěpánková et al. (2012).

\section{Euastrum binale Ralfs}

\section{Localities: $1,7,8$}

Rather rare in Central Europe (Růžička 1981), however Lhotský (1949) assumed it to be widely distributed across the whole Moravia. Nevertheless, this is after his record the only one from this region.

\section{Euastrum binale var. gutwinskii (Schmidle) Homfeld}

\section{Localities: 1, 6a, 6b}

Fig 3: 13

The taxon is relatively common in the Czech Republic with preference to acidic or slightly acidic habitats. From Moravia it was previously recorded by Fischer (1924, 1925), Lhotský (1949), Rybníček (1958) and Štěpánková et al. (2012).

\section{Euastrum dubium Nägeli}

Localities: $6 \mathrm{a}, 6 \mathrm{~b}$

It is rather rare in Moravia. We found it in slightly acidic to neutral habitats. Previous record: Kitner et al. (2004). 


\section{Euastrum elegans Ralfs}

Locality: 7

Fig 3: 11

The species was found in a mesotrophic acidic pool. From Moravia it was previously recorded by Růžička (1957) from the Hrubý Jeseník Mts.

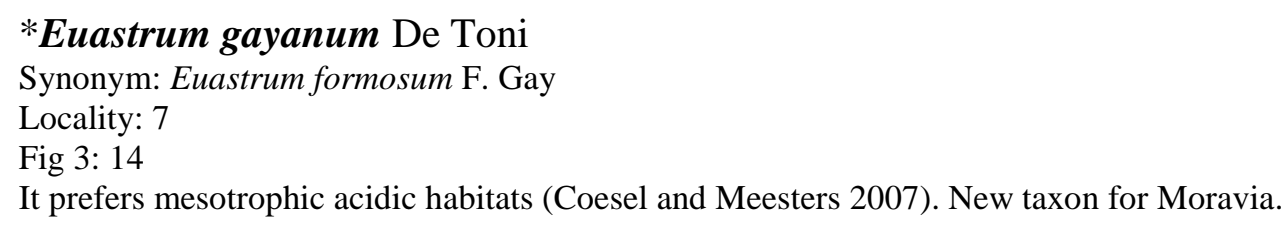

\section{Euastrum humerosum Ralfs}

\section{Locality: 6 a}

The species occurred in acidic to slightly acidic and neutral waters. From Moravia it is already known from the Jeseníky Mts, particularly in consequence with aerial liming (locality Trojmezí and Sedlo pod Vozkou; Štěpánková et al. 2012).

\section{Euastrum insulare (Wittr.) J. Roy}

Locality: $6 \mathrm{~b}$

Fig 3: 12

The species was found in a mesotrophic slightly acidic ephemeral ditch. Kitner et al. (2004) recorded it from the West Carpathians.

\section{Euastrum oblongum Ralfs}

Localities: 1, 2, 6a, 6b

Fig 3: 7

It occurred in slightly acidic mesotrophic habitats and was relatively abundant in the samples. From Moravia previously recorded by Kitner et al. (2004) and by Růžička (1957).

\section{Hyalotheca dissiliens Ralfs}

Localities: 1, 2, 6b, 7

Fig 1: 19

The nominate variety is much more common than other varieties in the Czech Republic. Although it is not extremely rare in Moravia, it was previously recorded only once by Růžička (1957).

\section{* Micrasterias americana Ralfs}

Synonyms: Euastrum americanum Ehr., Micrasterias americana var. taylori Krieger, M. morsa Ralfs

Locality: $6 \mathrm{~b}$

Fig 3: 4

Rather a rare species in the Czech Republic (Štastný 2010) occurred in our specimens in slightly acidic and neutral waters of ephemeral ditches. New taxon for Moravia.

\section{*Micrasterias denticulata var. angulosa (Hantzsch) W. et G. S. West}

Synonym: Micrasterias angulosa Hantzsch

Localities: $1,6 \mathrm{~b}$

Fig 3: 3

It is common in acidic, slightly acidic and neutral habitats (Růžička 1981). We were able to find specimens with its typical form, however according to Coesel and Meesters (2007), transitional forms to Micrasterias thomasiana var. notata are more common. It was reported several times from localities in Bohemia (Št'astný 2005 - nominate variety, 2008b - var. angulosa, 2009 - var. angulosa), but it can be classified as a very rare taxon in the Czech Republic. New taxon for Moravia.

\section{Micrasterias papillifera Ralfs}

Localities: 1, 2, 6a

Fig 3: 5

The species is relatively rare in the Czech Republic and occurs in slightly acidic habitats. Previous record from Moravia is from the locality Obidová (Kitner et al. 2004). 

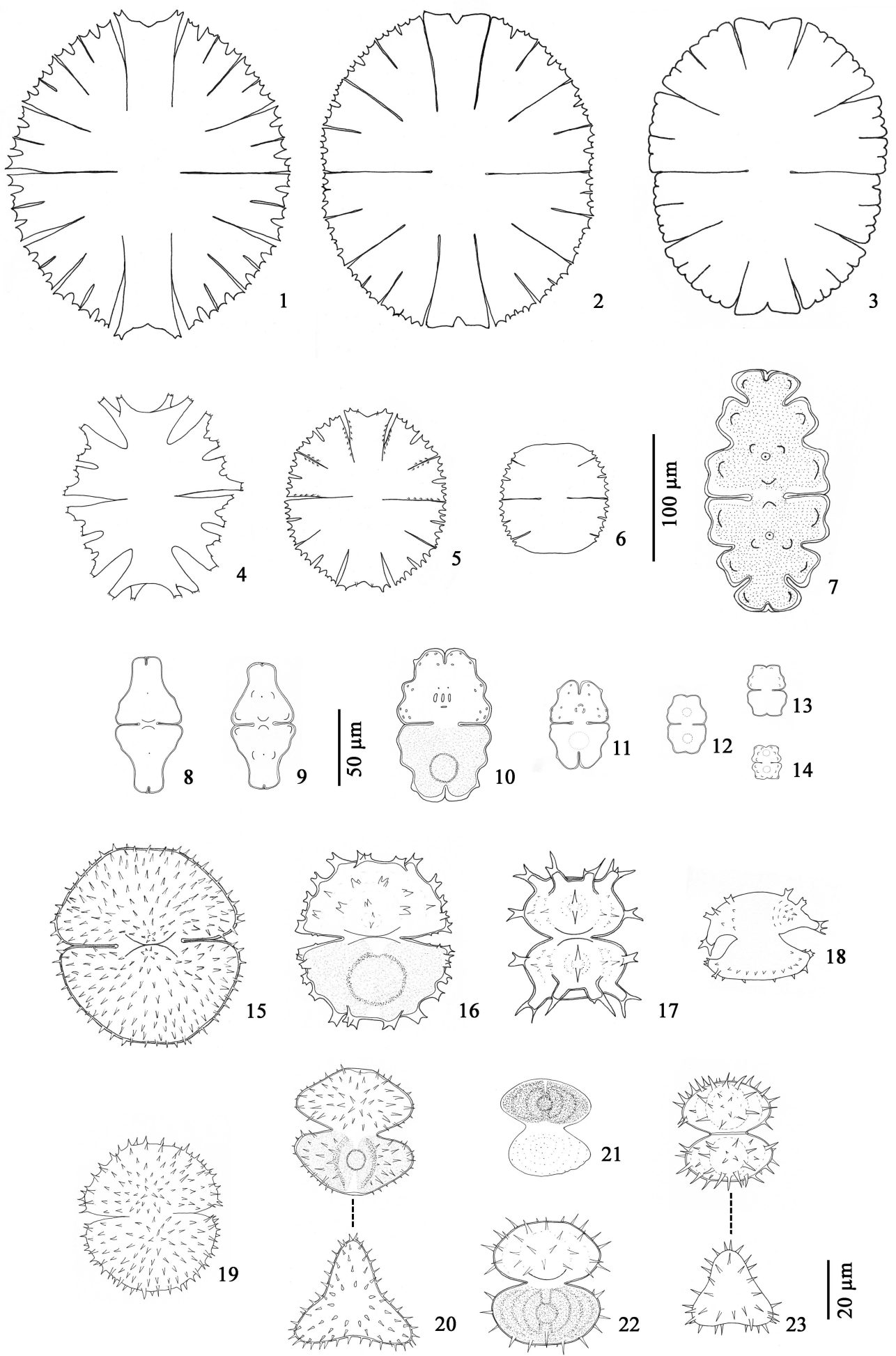

Fig 3: 1 - Micrasterias rotata, 2 - M. thomasiana var. notata, 3 - M. denticulata var. angulosa, $4-M$. americana, 5 - M. papillifera, 6 - M. truncata, 7 - Euastrum oblongum, 8-9 E. ansatum, 10 - E. bidentatum, 11 - E. elegans, 12 - E. insulare, $\mathbf{1 3}$ - E. binale var. gutwinskii, 14 - E. gayanum, 15 - Staurastrum pyramidatum, 16 - St. spongiosum var. perbifidum, 17 - St. senarium, 18 - St. controversum, 19 - St. hirsutum, 20 - St. kouwetsii, 21 - St. punctulatum, 22-23 St. teliferum var. ordinatum. Figs 1-6: scale $100 \mu \mathrm{m}$; 7-9: scale $50 \mu \mathrm{m}$; 10-23: scale $20 \mu \mathrm{m}$. 


\section{Micrasterias rotata Ralfs}

Localities: 2, $6 \mathrm{a}$

Fig 3: 1

Our populations were found in slightly acidic mesotrophic habitats. Although it is rather a rare species in the Czech Republic, over the years it was recorded from many places in Bohemia: Břehyně, Borkovická blata, Pískovny Cep, Rašeliniště Pele, Vizír (Št’astný 2005), Chvojnov (Št’astný 2008b), Slavkovský les (Trojánková 2006), localities Odměny and Staré jezero in the Třebon̆ basin (Chattová 2007); var. evoluta from Blatná and the Šumava Mts (Rosa 1951); var. pulchra from the Šumava Mts (Pascher 1906). From Moravia, it was known only from the locality Obidová (Kitner et al. 2004).

\section{* Micrasterias thomasiana W. Archer}

Synonym: Micrasterias denticulata var. subnotata W. West, M. denticulata $\mathrm{f}$. thomasiana (W. Archer) Jacobsen, Micrasterias thomasiana f. maior W. West

Localities: $6 \mathrm{a}, 6 \mathrm{~b}$

It was found in slightly acidic habitats. Although it was over the years several times recorded from Bohemia, it is rare in the Czech Republic (Štastný 2010). New taxon for Moravia. This species is listed in the Red Book of endangered and rare species of the Slovak and the Czech Republic (Kotlaba 1995).

\section{*Micrasterias thomasiana var. notata (Nordst.) Grönblad}

Synonym: Micrasterias denticulata var. notata Nordst.

Localities: 2, 6a, 7

Fig 3: 2

According to Coesel and Meesters (2007), it is more common than the nominal variety according to Růžička (1981) both varieties are quite frequent in the middle Europe. New taxon for Moravia.

\section{Micrasterias truncata Ralfs}

Localities: 1,2

Fig 3: 6

The species is relatively common in the Czech Republic. However, only two records are known from Moravia: the Jeseníky Mts (Růžička 1956) and the Beskydy Mts (Kitner et al. 2004).

\section{Pleurotaenium trabecula Nägeli}

Locality: 2

The species was found in a slightly acidic bog with Sphagnum. According to Rǔžička (1977), it often occurs in Central Europe. From Moravia previously recorded by Lelková et al. (2004) and by Sládečková et al. (1985).

\section{*Staurastrum controversum Ralfs}

\section{Synonym: Staurastrum anatinum var. controversum (Bréb. in Meneghini) Brook}

Localities: 6a, 7

Fig 3: 18

It was found in mesotrophic, acidic and slightly acidic waters. It is rather rare in the Czech Republic (Št'astný 2010). New taxon for Moravia.

\section{*Staurastrum dilatatum Ralfs}

Locality: 2

The species was found in a slightly acidic habitat. It is already known from Bohemia (e.g. Štastný 2010). New taxon for Moravia.

\section{Staurastrum furcatum var. aciculiferum (W. West) Coesel}

\section{Locality: 8}

It occurred in an acidic habitat with Sphagnum. From Moravia it is already known from the Jeseníky Mts (Rybníček 1958, Štěpánková et al. 2012), particularly from ombrotrophic mires.

\section{*Staurastrum gladiosum W. B. Turner}

\section{Locality: 7}

The species prefers mesotrophic peat bog pools of Holocene character (Coesel 1997; Coesel \& Meesters 2007). New taxon for Moravia. 


\section{Staurastrum hirsutum Ralfs}

Localities: $1,3,6 \mathrm{~b}, 8$

Fig 3: 19

The species inhabit acidic to slightly acidic waters. Although it used to be bound to oligotrophic habitats (Coesel and Meesters 2007), we found it in mesotrophic waters. From Moravia previously recorded by Štěpánková et al. (2012).

\section{*Staurastrum kouwetsii Coesel}

Localities: 2, 3, 6b

Fig 3: 20

According to Coesel and Meesters (2007), it is often misidentified as Staurastrum subbrebissonii or Staurastrum pilosum in algological literature. It occurs in acidic to slightly acidic mesotrophic habitats (e.g. Coesel 1997, 1998; Št’astný 2010). New taxon for Moravia.

\section{Staurastrum margaritaceum Ralfs}

Localities: 3, 6a, 6b, 8

The species inhabit acidic to slightly acidic waters. Coesel and Meesters (2007) characterized it as an oligotrophic species. However, we found it also in mesotrophic waters. It is not rare in the Czech Republic. Previous records from Moravia were made by Fischer (1924, 1925), Rybníček (1958) and recently by Štěpánková et al. (2012).

\section{Staurastrum orbiculare Ralfs}

Locality: 7

The species was rarely recorded in one of our samples. It was previously found in Moravia e.g. by Rybníček (1958) in the Jeseníky Mountains. Růžžčka (1958) found another variety, Staurastrum orbiculare var. extensum Nordst. in the same mountains.

\section{Staurastrum punctulatum Ralfs}

Locality: 7

Fig 3: 21

The species was found in an acidic bog pool. From Moravia previously recorded by Kitner et al. (2004) from the Beskydy Mts and by Štěpánková et al. (2012) from the Jeseníky Mts.

*Staurastrum pyramidatum $\mathrm{W}$. West

Synonyms: Cosmoastrum pyramidatum (W. West et G. S. West) Palamar-Mordvintseva, Staurastrum muricatum var. acutum W. West, S. muricum var. acutum W. West

Locality: 1

Fig 3: 15

The species was rare in the samples with dimensions: L: 67.5, B: 52.5-57.5 $\mu \mathrm{m}$. Our specimens corresponded to those depicted by Lenzenweger (1997), Plate 28: Fig. 1-2. It is a rare species in the Czech Republic (Štastný 2010). New taxon for Moravia.

\section{Staurastrum senarium Ralfs}

Synonym: Desmidium senarium Ehr.

Locality: 7

Fig 3: 17

We found the species in a mesotrophic peat bog pool of potential Holocene character. In Moravia previously recorded by Kitner et al. (2004).

\section{*Staurastrum sexcostatum cf. var.productum W. West}

\section{Synonym: Staurastrum sexcostatum subsp. productum W. West}

Locality: $6 \mathrm{~b}$

The taxon was found in a mesotrophic ephemeral ditch. It is rather rare in the Czech Republic (Štastný 2010). New taxon for Moravia. However, the validity of this variety is challenged (Guiry and Guiry 2012). 


\section{*Staurastrum spongiosum Ralfs}

Locality: $6 \mathrm{~b}$

The species was found in a slightly acidic, mesotrophic habitat. It is rare in the Czech Republic (Štastný 2010).

Dimensions: L: 50-55, B: 42.5-46, I: $17.5 \mu \mathrm{m}$. New taxon for Moravia.

\section{*Staurastrum spongiosum var. perbifidum W.West}

Locality: 6b

Fig 3: 16

We found this variety in slightly acidic, mesotrophic ephemeral ditches.

It is rare in the Czech Republic (Št'astný 2010). Our specimens corresponded to this depicted by Lenzenweger (1997), Plate 30: Fig. 12. New taxon for Moravia.

*Staurastrum subavicula (W. West) W. et G. S. West

Synonyms: Staurastrum arcuatum subsp. subavicula W. West, S. arcuatum var. subavicula W. West, S. vastum Schmidle

Locality: 7

The species was found in a mesotrophic acidic pool. It is a new record for Moravia. However, for Bohemia it was already recorded (e.g. Št’astný 2010).

\section{*Staurastrum teliferum Ralfs}

Locality: 7

The species occurred in acidic to slightly acidic bog pools. New taxon for Moravia.

\section{*Staurastrum teliferum var. ordinatum F. C. E. Børgesen}

\section{Locality: 6a}

Fig 3: 22-23

The variety was found in a mesotrophic slightly acidic bog. The nominate variety is already known from some Bohemian localities. Also variety ordinatum was previously reported by Rủžička (1973) from a Bohemian locality. However, our finding can be regarded as new record for Moravia. It could be caused by an uncertainty related to validity of this taxon (Coesel 1997).

\section{*Staurodesmus glaber (Ralfs) Teiling}

Synonyms: Arthrodesmus incus f. brebissonii Racib., A. ralfsii var. brebissonii (Racib.) G.M. Smith, Desmidium glabrum Ehr., Staurastrum glabrum Ehr. ex Ralfs

Locality: 7

Fig 1: 24

The species occurred in acidic bog pools. New record for Moravia.

\section{Tetmemorus granulatus Ralfs}

Localities: $1,2,3$

Fig 1: 16

The species was found in acidic, slightly acidic and rarely in neutral habitats. It was previously recorded from Moravia from the Jeseníky Mts (Lhotský 1949) and from the Beskydy Mts (Kitner et al. 2004).

\section{Tetmemorus laevis Ralfs}

Localities: 1, 2, 5, 6a

Fig 1: 17

The species was commonly found in acidic and slightly acidic habitats. Previous records from Moravia: Fischer (1924, 1925), Kitner et al. (2004), Poulíčková (1998), Růžička (1956, 1957) and Štěpánková et al. (2012).

Acknowledgements: We would like to thank to Dr. Zbyněk Hradílek from the Palacký University in Olomouc for his help in field sampling and to Mgr. Steven Morris for English language corrections. This research was supported by the projects: GACR 206/08/0389 of the Grant Agency of the Czech Republic; Prrf_2012_001 of the Internal Grant Agency of the Faculty of Science, Palacký University; PdF_2013_024 of the Internal Grant Agency of the Faculty of Education, Palacký University; CETPO CZ.1.07/2.3.00/20.0166. 


\section{References}

Brook A. J. (1981): The biology of desmids. University of California Press, Berkeley and Los Angeles.

Coesel P. F. M. (1975): The relevance of desmids in the biological typology and evaluation of fresh waters. Hydrobiological Bulletin 9: 93-101.

- (1982): De Desmidiaceeën van Nederland - Sieralgen. Deel 1 Fam. Mesotaeniaceae, Gonatozygaceae, Peniaceae. Wetenschappelijke Mededelingen KNNV, Hoogwoud NH.

- (1983): De Desmidiaceeën van Nederland - Sieralgen. Deel 2 Fam. Closteriaceae. Wetenschappelijke Mededelingen KNNV, Hoogwoud NH.

- (1985): De Desmidiaceeën van Nederland - Sieralgen. Deel 3 Fam. Desmidiaceae 1. Wetenschappelijke Mededelingen KNNV, Hoogwoud NH.

- (1997): De Desmidiaceeën van Nederland - Sieralgen. Deel 6 Fam. Desmidiaceae 4. Wetenschappelijke Mededelingen KNNV, Hoogwoud NH.

- (1998): Sieralgen en Natuurwaarden. Stichting Uitgeverij K. N. N. V., Utrecht.

- (2001): Biology and diversity of desmids. Compendium from training course, September 14-17, 2001. Dept. of Environm. Assesm., Swedish Univ. of Agricul. Sci., Uppsala.

Coesel P. F. M. \& Meesters K. J. (2007): Desmids of the Lowlands. Mesotaeniaceae and Desmidiaceae of the European Lowlands. KNNV Publishing, Zeist.

Chattová B. (2007): Algologická studie rašelinných okrajů rybníků Třeboňské pánve. (Bachelor thesis). Masaryk University in Brno.

Dočkal P. \& Sládeček V. (1974): Znečištění řeky Jihlavy u Třebíče. - Bulletin metod. střed. vodoh. laboratoří 25: $111-125$.

Fischer R. (1924): Ökologische Skizzen zur Algenflora des mährisch-schlesischen Gesenkes. - Schriften f. Süsswasser u. Meereskunde, Heft. 7: 1-20.

- (1925): Ökologische Skizzen zur Algenflora des mährisch-schlesischen Gesenkes. - Verhandl. d. Naturf. in Brünn 59: 3-11.

Guiry M. D. \& Guiry G. M. (2012): AlgaeBase. World-wide electronic publication, National University of Ireland, Galway. http://www.algaebase.org; searched on 15 November 2012.

- (2013): AlgaeBase. World-wide electronic publication, National University of Ireland, Galway. http://www.algaebase.org; searched on 11 February 2013.

Hašler P., Štěpánková J., Špačková J., Neustupa J., Kitner M., Hekera P., Veselá J., Burian J. \& Poulíčková A. (2008): Epipelic cyanobacteria and algae: a case study from Czech ponds. - Fottea 8 (2): 133-146.

Hindák F., Hindáková A., Marvan P., Heteša J. \& Hašler P. (2006): Diversity, abundance and volume biomass of the phytoplankton of the Morava River (Czech Republic, Slovakia) and Dyje River (Czech Rapublic) in November 2005. Diverzita, abundancia a objemová biomasa fytoplanktónu rieky Moravy (Česká republika, Slovensko) a rieky Dyje (Česká republika) v novembri 2005. - Czech Phycology 6: 7797.

Kitner M., Poulíčková A., Novotný R. \& Hájek M. (2004): Desmids (Zygnematophyceae) of the spring fens of a part of West Carpathians [Krásivky prameništ části západních Karpat]. - Czech Phycology 4: 4361.

Kočárková A. \& Poulíčková A. (2001): Algal species composition of pools in the Litovelské Pomoraví Protected Landscape Area [Druhové spektrum řas v planktonu tůní Litovelského Pomoraví]. - Czech Phycology 1: 37-44.

Kotlaba F. [ed.] (1995): Červená kniha ohrožených a vzácných druhů rostlin a živočichů SR a ČR, 4. díl (Sinice, řasy, houby, lišejníky, mechorosty). - Príroda, Bratislava.

Kouwets F. A. C. (1997): Contributions to the knowledge of the French desmid flora I. New and noteworthy taxa from the Central and Eastern Pyrenees. - Arch. Protistenk. 148: 33-51.

- (1999): A check-list of desmids (Chlorophyta, Zygnemaphyceae) of France. -Patrimoines Natureles 41: 1-148.

Lelková E., Kočárková A. \& Poulíčková A. (2004): Phytoplankton ecology of two floodplain pools near Olomouc [Ekologie fytoplanktonu dvou tůní u Olomouce]. - Czech Phycology 4: 111-121.

Lenzenwe ger R. (1996): Desmidiaceenflora von Österreich. Teil 1. J. Crammer, Stuttgart.

- (1997): Desmidiaceenflora von Österreich. Teil 2. J. Crammer, Stuttgart.

- (1999): Desmidiaceenflora von Österreich. Teil 3. J. Crammer, Stuttgart.

- (2003): Desmidiaceenflora von Österreich. - In: Crammer, J. (ed.): Bibliotheca Phycologica 111/4: 1-87 pp. Gebrüder Borntraeger Verlagsbuchhandlung, Berlin-Stuttgart.

Lhotský O. (1949): Poznámka k flóře Desmidiaceí Hrubého Jeseníku. - Časopis Vlast. spolku mus. v Olomouci 58: 149-155.

Losos B. \& Heteša J. (1972): Plankton plůdkových rybníků. UJEP, Brno. 
Losos B. \& Marvan P. (1957): Hydrobiologické poměry řeky Moravice a jejích přítoků Podolského a Černého potoka. - Sborník Vysoké školy zemědělské a lesnické v Brně, řada A: Spisy fakulty agronomické a zootechnické 1: 41-69.

Lukavský J. (2009): Algae, Cyanobacteria and Chytridiales of Černé Lake in the Bohemian Forest (Šumava, Czech Republic). - Silva Gabreta 15 (1): 1-48.

Marvan P. (1998): Řasová flóra stojatých vod, mokřadů a toků širší oblasti vlivu energetické soustavy Dukovany-Dalešice. - Přírod. Sbor. Západomorav. Muz. Třebíč 34: 1-136.

Mix M. (1972): Die Feinstruktur der Zellwände bei Mesotaeniaceae und Gonatozygaceae mit einer vergleichenden Betrachtung der verschiedenen Wandtypen der Conjugatophyceae und über deren systematischen Wert. - Archiv für Mikrobiologie 81: 197-220.

Neustupa J., Černá K. \& Št’astný J. (2009): Diversity and morphological disparity of desmid assemblages in Central European peatlands. - Hydrobiologia 630 (1): 243-256.

Nováková S. (2002): Algal flora of subalpine peat bog pools the Krkonoše Mts. - Preslia 74: 45-56.

Pascher A. (1906): Neuer Beitrag zur Algenflora des südlichen Böhmerwaldes. - Lotos 54: 1-36.

Poulíčková A. (1987): Algae in ground water below the active stream of a river (Basin of the Morava River, Czechoslovakia). - Arch.Hydrobiol. / Suppl. 78, Algological Studies 46: 65-88.

- (1998): Významné algologické lokality po padesáti letech I. Prameny Střední Opavy [Important algological localities after the period of 50 years]. - In: Poulíčková, A. and Palochová, A. eds. (1998): Sborník referátů 38. prac. konf. AS ČBS.

- (2011): Základy ekologie sinic a řas. UP Olomouc, Olomouc.

Poulíčková A., Bergová K., Hnilica R. \& Neustupa J. (2013): Epibryic diatoms from ombrotrophic mires: diversity, gradients and indicating options. - Nova Hedwigia (In press).

Poulíčková A., Lhotský O. \& Dřímalová D. (2004): Prodromus sinic a řas České Republiky. - Czech Phycology 4: 19-33.

Reichholf J. (1998): Pevninské vody a mokřady. Ekologie evropských sladkých vod, luhů a bažin. Ikar, Praha.

Rosa K. (1951): Algenflora von Südböhmen I. Die Algen der Umgebung von Blatná. - Studia Botanica Cechoslovaca 12: 173-232.

- (1957): Výzkum mikroedafonu ve smrkovém porostu na Pradědu. - Př́rodovědecký sborník Ostravského kraje 18 (1):17-73.

- (1969): Př́íspěvek k výzkumu řasové flory v okolí Vlašimi II. - Sborník vlastivědných prací z Podblanicka, Benešov 10: 32-75.

Roubal J. (1938): Flora desmidiaceí rašelinných jam u Příbraze. - Čas. Nár. Mus. 112: 83-95.

- (1958): Desmidiologické poznámky. - Sborník Vyšší pedagogické školy v Plzni, biologie-chemie 1: 71-124.

Růžička J. (1954): Krásivky (Desmidiaceae) řeky Moravice a jejích přítoků. - Přírodov. sbor. Ostravského kraje 15: 290-303.

- (1956): Krásivky pramenů Moravice (Velká Kotlina, Jeseníky). - Př́rodov. sbor. Ostravského kraje 17: 38-58.

- (1957): Krásivky z prameništ' na Malém Dědu (Hrubý Jeseník). - Časopis Slezského muzea 6: 108-121.

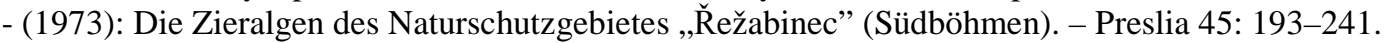

- (1977): Die Desmidiaceen Mitteleuropas. Band 1, 1. Lieferung. E. Schweizerbart'sche Verlagsbuchhandlung, Stuttgart.

- (1981): Die Desmidiaceen Mitteleuropas. Band 1, 2. Lieferung. E. Schweizerbart'sche Verlagsbuchhandlung, Stuttgart.

Rybníček K. (1958): Krásivky pramenné oblasti Branné v Hrubém Jeseníku. - Přírodov. sbor. Ostravského kraje 19: 97-122.

Sládečková A., Sládeček V. \& Musilová J. (1985): Jakost vody ve vodárenských nádržích Fryšták, Ludkovice a Slušovice. - Vodní Hosp. B 35 (2): 39-42.

Št’astný J. (2005): Diverzita a ekologie krásivek ve vybraných oblastech České republiky. (Master's thesis). Charles University in Prague.

- (2007): Die Desmidiaceenflora von Pískovny Cep (Südböhmen). - Novit. Bot. Univ. Carol. 18: 53-62.

- (2008a): Desmids from ephemeral pools and aerophytic habitats from the Czech Republic. - Biologia 63 (6): 888-894.

- (2008b): Krásivky Přírodních rezervací „Chvojnov“ a „Na Oklice“. [Desmids of the Nature Reserves „Chvojnov“" and „Na Oklice“]. - Acta rerum naturalium 4: 13-16.

- (2009): The desmids of the Swamp Nature Reserve (North Bohemia, Czech Republic) and a small neighbouring bog: species composition and ecological condition of both sites. - Fottea 9 (1): 135-148.

- (2010): Desmids (Conjugatophyceae, Viridiplantae) from the Czech Republic; new and rare taxa, distribution, ecology. - Fottea 10 (1): 1-74.

Št'astný J. \& Kouwets F. A. C. (2012): New and remarkable desmids (Zygnematophyceae, Streptophyta) from Europe: taxonomical notes based on LM and SEM observations. Fottea 12: 293-313. 
Štěpánková J., Vavrušková J., Hašler P., Mazalová P. \& Poulíčková A. (2008): Diversity and ecology of desmids of peat bogs in the Jizerské hory Mts. - Biologia 63: 891-896.

Štěpánková J., Hašler P., Hladká M. \& Poulíčková A. (2012): Diversity and ecology of desmids of peat bogs in the Jeseníky Mts.: Spatial distribution, remarkable finds. - Fottea 12 (1): 111-126.

Trojánková K. (2006): Krásivková flóra CHKO Slavkovský les. - Erica 13: 3-15.

West W. \& West G. S. (1905): A monograph of the British Desmidiaceae, Vol. II. - The Ray Society, London.

- (1908): A monograph of the British Desmidiaceae, Vol. III. - The Ray Society, London.

- (1912): A monograph of the British Desmidiaceae, Vol. IV. - The Ray Society, London.

Woelkerling W. J. \& Gough S. B.: (1976): Wisconsin desmids, III. Desmid community composition and distribution in relation to lake type and water chemistry. - Hydrobiologia 51 (1): 3-31.

Authors' address: Petra Mazalová \& Aloisie Poulíčková, Department of Botany, Faculty of Science, Palacký University, Šlechtitelů 11, CZ-783 71 Olomouc, Czech Republic, e-mail: petra.mazalova@upol.cz (corresponding author)

Jana Štěpánková, Department of Biology, Faculty of Education, Palacký University, Purkrabská 2, CZ-779 00 Olomouc, Czech Republic 